\title{
ПСИХОЛОГО-ПЕДАГОГІЧНІ АСПЕКТИ РОЗВИТКУ ПРОФЕСІЙНОЇ ТВОРЧОСТІ СТУДЕНТІВ
}

\begin{abstract}
У статті подано теоретичний огляд $і$ аналіз наукової літератури з проблеми розвитку професійної творчості в сучасній психології, визначено психолого-педагогічні засади та перспективи розвитку професійного мислення у студентів.

Ключові слова: професійне мислення, технічне мислення, технічна творчість, розв'язання навчальних задач професійного спрямування.
\end{abstract}

В статье представлен теоретический обзор и анализ научной литературы по проблеме развития профессионального творчества в современной психологии, указаны психолого-педагогические условия и перспективы развития профессионального мышления у студентов.

Ключевые слова: профессиональное мышление, техническое творчество, решение учебных задач профессионального направления.

In the article a theoretical survey and analysis of scientific literature about professional creativity developing in up-to-date psychology, psychological and pedagogical fundamentals of students' thinking are discussed and characterized in the article.

Key words: professional thinking, technical thinking, technical creative activity, educational problems of professional direction solving.

Сучасна психолого-педагогічна наука вважає, що інновації в навчанні - це не лише ідеї, підходи, методи, технології, які ще не використовувалися, а й той комплекс елементів педагогічного процесу, що дозволяє ефективно розв’язувати завдання розвитку й саморозвитку творчої особистості.

Професійна діяльність у сучаних умовах праці потребує від фахівців розвиненого професійного мислення, професійної творчості. Професійна творчість - це знаходження нових нестандартних способів розв'язання фахових завдань, аналіз професійних ситуацій, прийняття професійних рішень. Результатами професійної творчості можуть бути: нове розуміння предмета праці (нові ідеї, закони, концепції, принципи), новий підхід до реалізації професійних дій (нові моделі, технології, правила), одержання нових результатів у професійній діяльності тощо.

Дослідження професійної технічної творчості у психології проводяться з початку ХХ століття та особливо інтенсивно розробляються нині, це відображено в працях В. Алексєєва, А. Антонова, Г. Василевської, Є. Верещака, Ю. Гільбуха, С. Губенкова, О. Зазимка, О. Коркунової, А. Маркової, В. Моляко, В. Путиліна та ін.

Проведений аналіз психолого-педагогічних досліджень дозволяє зробити припущення, що професійна творчість створює сприятливі умови для розвитку професійного мислення студентів, оскільки спрямована на створення принципово нових технічних механізмів, на пошук для існуючих приладів нових можливостей використання. Зважаючи на це, професійна технічна творчість може мати різні рівні залежно від іiі результатів :

- вищий рівень, результатом якого $є$ принципово нові винаходи чи науково-технічні відкриття, що роблять революцію в науці та технології;

- середній рівень, результатом якого $є$ удосконалення технічного обладнання та технології;

- нижчий рівень, результатом якого $€$ використання наявних технічних приладів і засобів виробництва в нових, не притаманних їм функціях, які все ж таки задовольняють потреби в удосконаленні виробництва [2].

Вищий рівень технічної творчості можна віднести до винахідництва, середній та нижчий - до раціоналізації. Винахідництво - це нове, суттєво відмінне технічне розв'язання завдання в будь-якій галузі народного господарства, що дає позитивний ефект виробництву (конструктивні прилади, технологічні способи, нові машини, механізми тощо).

Творчість сприяє виробленню вмінь розв'язувати різні завдання, орієнтуватися в нових умовах, переборювати труднощі, вона збуджує та стимулює розвиток інтересів до діяльності, оскільки завжди пов'язана 3 відкриттям нового, знаходженням чогось раніше невідомого. Творча праця - особливо складна, і навчання в умовах творчої праці якоюсь мірою гарантує в подальшому успішну діяльність, а також постійну спрямованість на її раціоналізацію, поліпшення якості та підвищення ефективності. Зокрема, виявлено позитивну роль творчості у стимулюванні пізнавальних інтересів, допитливості, розвитку професійного мислення, дослідницької активності, здатності знаходити оригінальні рішення.

Технічна творчість зорієнтована насамперед на розвиток виробництва: на проектування, розроблення, використання удосконалених та якісно нових технологій, знарядь і предметів праці. Професійне творче мислення представляє собою такий рівень розвитку інтелекту, який надає можливість фахівцю знаходити нове, оригінальне розв'язання виробничої проблеми.

Досліджуючи питання технічної творчості, Г. Альтшуллер теоретично обгрунтував і практично довів, що винахідництво - процес керований [7]. Вихідним положенням його теорії $є$ таке: технічні 
об'єкти, як і будь-які об'єктивні системи, у своєму розвиткові підкоряються певним законам. У процесі вивчення цих законів ученим розроблено алгоритм розв'язання винахідницьких задач (AРВ3), де основним є поняття технічної суперечності. Максимальне загострення суперечності i їх розв’язування за допомогою типових прийомів призводить до принципово нових, винахідницьких рішень, які усувають саме причину виникнення технічної суперечності. Методика Г. Альтшуллера передбачає послідовність, яка допомагає уникнути помилок під час розв'язування. Розглядаючи задачі за кроками, не слід звертати уваги на варіанти розв’язань, які виникають паралельно. Навіть якщо із самого початку знайдено правильне розв’язання, розбір потрібно провести до кінця.

В. Моляко, як один із провідних дослідників цієї проблеми, називає такі ознаки технічної творчості: інтерес до техніки, який виявляється через розв’язання задач, творчий конструкторський задум, технічна винахідливість, уміння використовувати логічні принципи, схильність до набуття технічних знань, уміння кодувати технічні образи та поняття [3].

На матеріалі проектно-конструкторської діяльності В. Моляко визначає чотири основні рівні конструювання: найпростіший, репродуктивний, продуктивний, творчий.

Найпростіший рівень характеризується обмеженістю елементів та виокремленням найпростіших структур, безпосереднім об'єднанням частин завдання. Залежно від складності предмета, який потрібно створити, формуються репродуктивний, продуктивний і творчий рівні.

Репродуктивний рівень пов'язаний із конструюванням за кресленнями й макетами. Це дублююче конструювання, в основу якого покладено використання готового об'єкта без змін або 3 незначними змінами.

Продуктивний рівень конструювання - це створення нових деталей, вузлів, механізмів, машин, приладів на основі вже розроблених та відомих, але з упровадженням значних їх змін. Продуктивне конструювання грунтується на пошуку аналогів, на перекомбінуванні та реконструкції, але якою б не була новою конструкція, все-таки передбачається знайомство із старою, іiі кресленнями, макетами, характеристиками тощо.

Вища форма продуктивного конструювання - творче конструювання. Цей рівень передбачає створення нової конструкції тільки за рахунок уяви, фантазії, виникає випадково, пов'язаний 3 інтуїтивним мисленням, однак трапляється, як указує В. Моляко, дуже рідко.

Активізації і розвиткові професійного мислення студентів у навчально-виховному процесі сприяє використання тренінгових занять. Проблема застосування різних видів тренінгу для найрізноманітніших змін широко обговорюється в сучасній психологічній літературі. Для позначення цього методу вживаються назви «активна соціально-психологічна підготовка», «активні групові методи навчання», «групи інтенсивного спілкування», «соціально-психологічний тренінг», «творчий тренінг», «тренінг сенситивності», «мотиваційний тренінг» тощо. Як зазначає Л. Петровська, соціально-психологічний тренінг - засіб психологічного впливу, спрямований на розвиток знань, соціальних установок, умінь і досвіду в міжособистісному спілкуванні. Ю. Макаров характеризує тренінг як діяльність, яка спрямована на набуття знань, умінь і навичок, корекцію й формування здібностей i настанов, необхідних для успішного виконання професійної діяльності. Однак, незважаючи на значну кількість досліджень 3 проблем психологічного тренінгу, нині не існує загальноприйнятого наукового визначення психологічного тренінгу, а діяльність практиків у галузі тренінгу грунтується на різноманітних концептуальних підходах, кожен із яких має свої обмеження щодо їх ефективності та застосування.

Задля успішного розвитку професійного мислення у студентів у вивченні спеціальних дисциплін ефективним $є$ проведення тренінгу розвитку професійної творчості. Тренінг розвитку професійної творчості - це система занять зі спеціальних дисциплін, на яких створюються сприятливі психологічні умови для реалізації творчого потенціалу студентів, їх розвитку і засвоєння прийомів творчої діяльності. Одне з основних завдань проведення тренінгу -стимулювання інтересу студентів до проблеми, для вирішення якої необхідне набуття знань і умінь, та розв'язання цієї проблеми через практичне застосування набутих знань. Тренінг розвитку професійної творчості зорієнтований на самостійну діяльність студентів протягом певного проміжку часу. Він передбачає використання різноманітних прийомів і засобів навчання та інтегрування різних знань.

Іноді умови не дозволяють використовувати тренінгове заняття в повному обсязі як форму організації навчально-виховного процесу. У такому разі доцільно використовувати елементи тренінгу, на що достатньо відводити $10-15$ хв. кожного заняття.

Проведення тренінгу розвитку професійної творчості в групі без доброзичливої атмосфери неможливе, тому потрібно їі створити й постійно підтримувати. До кожного заняття викладачеві слід сумлінно готуватися. Необхідно простежити, щоб до роботи був залучений кожен студент, постійно контролювати процес досягнення поставлених цілей (вони повинні бути чітко сформульованими та легко контрольованими), у разі невдачі - бажано переглянути стратегію й тактику роботи, шукати й виправляти їі недоліки. Однак заняття не має бути перевантаженим інтерактивною роботою. Не варто використовувати один і той же метод кілька разів поспіль, слід поєднувати різноманітні методи самостійний пошук, традиційні методи (розповідь, бесіда, демонстрування та інші). 
У процесі виховання творчого начала важлива роль належить викладачеві, який здатний спрямувати студентів на шлях пошуків, допомогти їм увійти в атмосферу творчості, в коло ідей, робота над якими розкриває широкі можливості для самостійного пошуку і нових знахідок. Проте без особистого захоплення пізнанням, професійної компетентності цього досягнути складно.

Зважаючи на це, для успішної роботи 3 розвитку творчого професійного мислення студентів, бажано, щоб викладач мав такі якості:

- прагнення до максимальної гнучкості (імпровізація, вміння враховувати найменші зміни у психолого-педагогічній ситуації і відповідно змінювати свою поведінку);

- виявлене прагнення до самоактуалізації;

- здатність до емпатії, сензитивність до потреб студентів;

- емоційну врівноваженість, упевненість у собі;

- настанову на створення позитивного самосприйняття студентів;

- здатність надавати викладанню особистісного емоційного забарвлення;

- володіння стилем неформального спілкування, надання переваги усним, а не письмовим контактам.

Кожен викладач повинен знати, що від уміння зацікавити спеціальною дисципліною, яка вивчається, багато в чому залежить успіх заняття. Адже інтерес $є$ важливим фактором розвитку особистості студента в цілому, і його творчих здібностей зокрема. Прагнучи розвивати професійну творчість, творчі здібності студентів, викладачеві варто звернути увагу на психологічно значущі положення: 1) бажано враховувати такі характеристики, як вік, стать, індивідуально-психологічні особливості кожного студента (мислення, уяви, уваги, пам'яті, емоційного стану); для цього до початку проведення навчально-тренінгових занять необхідно, за можливості, з'ясувати психологічну готовність студентів до діяльності, їх самооцінку; 2) необхідно враховувати специфіку дисципліни і теми, що вивчається, водночас розвивати пізнавальний інтерес до спеціальної дисципліни. 3) заздалегідь опрацьовувати використання різних видів запитань, якими можна активізувати студентів у випадку пасивності, невпевненості; 4) під час проведення навчально-тренінгових занять підбадьорювати студентів, налаштовувати на успіх, залучати до активної роботи усіх учасників. Кожен студент повинен вірити в можливість знайти правильне, цікаве, творче рішення. 5) здійснюючи спілкування і взаємовідносини під час тренінгу, кожен учасник повинен зважати на інтереси, цінності, почуття, переживання інших; 6) бажано виявляти зацікавленість до кожного без винятку учасника тренінгу та помічати будь-які позитивні зміни; бажано заохочувати ініціативу та самостійність студентів.

Однак нині в педагогічному середовищі побутує думка про неготовність значної частини викладачів включатися в інноваційні процеси. I для цього $є$ певні підстави. Так, прагнення викладача забезпечити максимальну відповідність навчально-виховного процесу вимогам освітньої системи призводить до того, що студент використовується як засіб діяльності.

На думки педагогів, перешкодами у засвоєнні та розробленні нововведень є: 1) недостатня інформованість щодо нововведення в освіті; 2) відсутність або недостатній розвиток дослідницьких умінь; 3) відсутність часу.

Отже, допомога, якої потребують педагоги, - це методичні посібники та консультування, майстеркласи та тренінги. Тому головною метою діяльності адміністрації вищого на-вчального закладу має стати створення умов, за яких спостерігається зростання особистості викладача. Створення таких умов не означає лише фінансове стимулювання діяльності викладача, оскільки грошова винагорода не спонукає до виконання роботи на високому рівні, а є лише мотивом до здобуття цієї винагороди. Недостатнім виявляється і покращення матеріально-технічної бази: бібліотечний фонд, методичний кабінет, найсучасніше обладнання відокремлено не розглядаються педколективом як рушійні мотиви подальшого професійного зростання (хоча й визнаються сучасним педагогічним менеджментом), це засоби, що полегшують навчально-виховний процес. Тому наявність матеріально-технічної бази не сприяє особистісній зацікавленості конкретного викладача в ії використанні. Така зацікавленість зумовлена внутрішньою мотивацією викладача до подальшого особистісного й професійного зростання.

1. Валиуллина Г. Г. Возрастно-половые особенности развития профессионального мышления студентов: автореф. дис. на соискание ученой степени канд. психол. наук: спец. 19.00.13 «Психология развития, акмеология» / Г. Г. Валиуллина. - Астрахань, 2007. - 27 с. 2. Джелілова Л. Р. Психологічні особливості розвитку професійного мислення у майбутніх учителів початкової школи: автореф. дис. на здобуття наук. ступеня канд. психол. наук: спец. 19.00 .07 «Педагогічна та вікова психологія» / Джелілова Л. Р. - Одеса, 2008. 19 c. 3. Костюк Г. С. Учебно-воспитательный процесс и психическое развитие / Г. С. Костюк [под ред. Л.Н.Проколиенко]; [сост. В. В. Андриевская, Г. А. Балл, А. Т. Губко, Е. В. Проскура]. - К. : Радянська школа, 1989. - 608 с. 4. КЛимов Е. А. Путь в профессию / Е. А. Климов. - Л. : Лениздат, 1974. - 190 с. 5. Рубинштейн С. Л. О мышлении и путях его исследования / С. Л. Рубинштейн. - М. : Изд-во АН СССР, 1958. - 147 с. 6. Теплов Б. М. Избранные труды: в 2 т. / Б. М. Теплов. - М. : Педагогика, 1985. - Т. 1. - 328 с. 7. Ягупова О. В. Особливості розвитку практичного мислення майстрів виробничого навчання: автореф. дис. на здобуття наук. ступеня канд. психол. наук: спец. 19.00.03 «Психологія праці; інженерна психологія» / О. В. Ягупова. - Харків, 2009. - 20 с. 